\title{
Age determination in the icefish Pseudochaenichthys georgianus (Channichthyidae) based on multiple methods using otoliths
}

\author{
Ryszard Traczyk $^{1}$, Victor Benno Meyer-Rochow ${ }^{2,3, *}$, Robert M. Hughes ${ }^{4,5}$ \\ ${ }^{1}$ University of Gdańsk, Department of Oceanography and Geography, 81-378 Gdynia, Poland \\ ${ }^{2}$ Department of Ecology and Genetics, Oulu University, 90140 Oulu, Finland \\ ${ }^{3}$ Agricultural Science and Technology Research Institute, Andong National University, Andong 36729, Republic of Korea \\ ${ }^{4}$ Amnis Opes Institute, Corvallis, Oregon 97333, USA \\ ${ }^{5}$ Department of Fisheries \& Wildlife, Oregon State University, Corvallis, Oregon 97331, USA
}

\begin{abstract}
Aging Antarctic icefish is difficult because of their lack of scales and poorly calcified bones. Icefish ages must therefore be estimated from otoliths. We describe a method of reading daily micro-increments in connection with shape, size and mass analyses of the otoliths of the South Georgia icefish Pseudochaenichthys georgianus. Changes in otolith morphology and mass correlate with fish size and age group. The otolith micro-increment analysis is capable of establishing the age of an icefish by relating the daily micro-increment count to the life history of the fish. Micro-increment measurements and analyses are relatively simple to do by light and scanning electron microscopy and by using micro-densitometer and digitizing equipment. Drastic changes in the life history of an individual are reflected by measurable changes in its otolith microincrement data as seen in our analyses of age groups $0-\mathrm{VI}$. The initial drastic change in daily micro-increment shapes and periodicities occur in connection with the hatching period of the icefish. The next drastic change in otolith shape and daily micro-increments occurs when $\sim 7 \mathrm{~cm}$ long fish shift from pelagic to benthic habitats. As the fish age beyond group III, individual otolith variability lessens until they begin spawning. Our results indicate a single population of $P$. georgianus between the Antarctic Peninsula and South Georgia.
\end{abstract}

KEY WORDS: Southern Ocean $\cdot$ Daily micro-increments $\cdot$ Light microscopy $\cdot$ Scanning electron microscopy $\cdot$ Aging analyses

\section{INTRODUCTION}

Age assessments provide essential information about population structure and population growth resulting from environmental changes. Fish age classes can be estimated in several ways. One method is to measure body lengths of multiple individuals in a population from the time of hatching and then to plot those lengths as histograms. However, young fish grow rapidly until reaching sexual maturity, but thereafter length increases are less

\footnotetext{
*Corresponding author: meyrow@gmail.com
}

dramatic, because more energy is channeled into reproduction than somatic growth. Age estimation is also based on the number of seasonal growth marks present on otoliths, scales or bones. The widths of these seasonal increments vary in successive years of the life of a fish (i.e. widths increase during summer high-growth periods but narrow during winter slow-growth periods). These yearly increments are easily distinguished in fish of climate zones with distinct seasons and in species that exhibit vertical migrations.

(C) The authors 2021. Open Access under Creative Commons by Attribution Licence. Use, distribution and reproduction are unrestricted. Authors and original publication must be credited. 
Although the growth of a fish slows as it ages, all fish grow continually. The age of a fish not only affects its body length but also the size, mass and shape of its otoliths because changes in body shape and mass are reflected in similar changes in its otoliths to retain its ability to remain in neutral balance. Different age groups can therefore be identified on the basis of daily otolith micro-increments, otolith diameter, otolith shape and otolith mass, and by the presence or absence of a secondary primordium and/or an anterior colliculum. These age-related changes reflect the role of otoliths as gravity and swimming monitors and the varied sensory functions that otoliths play during the different growth stages and environments of the fish.

Age groups of South Georgia icefish Pseudochaenichthys georgianus are distinct and differences between them include body size, otolith dimensions and otolith mass. The large separation of different age groups results from the influence of the environment on reproduction. Ice conditions that prevail over most of the year restrict maturation and maximize growth during the short summer months that the fish spend inshore or over warmer shelf localities. This leads to successive groups of equal-aged and -sized fish (North 1990). However, in case of unfavorable conditions, mature icefish may skip spawning, reduce growth and suppress maturity (Ghigliotti et al. 2017), thereby causing a weaker than normal icefish cohort in that year (Traczyk \& Meyer-Rochow 2019, Traczyk et al. 2020). In some cases, older fish may become smaller owing to a lack of food and desorption of body tissue. Therefore, age estimation of older fish based on body length becomes unreliable (Magnifico 2007).

Nonetheless, members of the same icefish age group are typically characterized by similar sizes, low variation in morphological descriptors and large separation from non-members. If there are shared sizes between older age groups, large individual variability appears in those classes. Because hatching of $P$. georgianus occurs only during one short period each year, its generations are well separated in size by at least 1 yr of fast growth, and are therefore clearly distinguishable (Magnifico 2007, Traczyk \& Meyer-Rochow 2019).

It is impractical to determine icefish ages by measuring yearly body length increases since the time of hatching from commercial catch records because those catches lack sub-adult fish and their lack of scales means that icefish ages must be estimated from otoliths or other bones. However, their bones are largely replaced by cartilage and their skeletons undergo constant metamorphosis (Żabrowski 2000), which excludes skeletal bone from icefish aging. Therefore, otoliths have become the aging structure of choice (Kock 1989, Florin et al. 2018). Of the 3 otoliths in the head, the sagittae show the greatest increase in size as the fish grows and are therefore preferred for aging (Kock 1989). Hereafter, we simply refer to the sagitta as the otolith. Icefish otoliths are weakly ossified and fragile; therefore, they are easily broken or cracked, hindering accurate aging. In addition, otolith pre-treatments for light microscope examination often make them too dark or too transparent to read the annuli accurately (Kock 1989). Moreover, annuli examined by transmitted or reflected light are difficult to interpret, and Antarctic waters experience weak seasonality, making icefish growth patterns difficult to interpret. Furthermore, otolith shapes change with the changing life histories of icefish, becoming longer because of increased vertical migration and having longer collicula because of increased swimming activity and greater gamete mass.

Traditionally, as with other fish species, icefish otoliths are read by counting the number of annual increments visible by light microscopy. Mucha (1980) reported many problems preparing and reading $P$. georgianus otolith annuli by light microscopy, and therefore his published growth rates for $P$. georgianus are inaccurate and imprecise. Four papers have dealt with age estimates in $P$. georgianus individuals (Mucha 1980, Chojnacki \& Palczewski 1981, Kellermann et al. 2002, Traczyk 2015a), but only 2 of these provided preliminary data on daily microincrements in larvae (Kellermann et al. 2002, Traczyk 2015a). The limited availability of larval and early juvenile specimens of $P$. georgianus further increases the difficulties of age studies in this species. A method to determine where juvenile specimens occur in the early phase of their lives involves analyses of the carbon/oxygen isotope compositions of otoliths (MeyerRochow et al. 1992). However, lack of information on isotopic characteristics of oceanic Antarctic regions has precluded the use of this method for $P$. georgianus. Consequently, previous light-microscope methods of icefish aging continue to be used despite being fraught with errors and confusion that confound the accurate and precise aging of these fish.

Biomass estimates from surveys indicate that $P$. georgianus stocks have decreased (Radtke \& Shafer 1988 ) to $<25 \%$ of their levels before exploitation (Sosinski \& Szlakowski 1992). Intensive fishing in 1970-2000 (Everson 1994, Kock et al. 2000) and a scarcity or overexploitation of krill (Euphausia superba) 
that caused fur seals to shift their diets to feed on icefish may explain the decline in icefish numbers (Everson et al. 1999). Fishing is still allowed for smaller icefish species (CCAMLR 2019), but $P$. georgianus occurs in large amounts as bycatch. Therefore, there is a need for better information on growth variability, life history and population processes affecting the species, all of which depend on reliable assessments of individual fish ages.

$P$. georgianus lack hemoglobin in their blood and myoglobin in their skeletal muscles, relying instead on the high amounts of oxygen dissolved in the cold Antarctic water (Sidell \& O'Brien 2006). Their bodies are scaleless, which decreases body resistance and saves energy during swimming. Icefish possess relatively large hearts and greater blood volumes than most fish and are ambush feeders, waiting until prey are close enough to lunge at (LaMesa 2004, Kock 2005). Adult $P$. georgianus, some of which are largely piscivorous (LaMesa 2004), live on island shelves and feed on krill (69\%), fish (22\%) and mysids (9\%). Larvae and juveniles occur in the pelagic zone, often with krill (Linkowski \& Rembiszewski 1978, Kock 1981). At South Georgia, spawning occurs in April (Kock \& Kellermann 1991, Vanella et al. 2005) and 1 to 2 mo later at South Orkney and until August further south at Elephant Island (Kock et al. 2000). Members of one generation spawn eggs simultaneously (Militelli et al. 2015). The eggs measure approximately $4 \mathrm{~mm}$ in diameter and are probably demersal. Larvae, 15-20 mm long, are thought to hatch in May at South Georgia and around September at South Orkney (Efremenko 1983, Kock \& Kellermann 1991). Mature fish reach lengths of $41-56 \mathrm{~cm}$ and weights of 2.3-2.5 kg (Permitin 1973, Kock 1981).

Fishing on the shelf has been banned since 1990, but considerable fishing on the slope for toothfish Dissostichus eleginoides and krill still occurs. Lack of krill from fishing off the Antarctic Peninsula (the krill source for South Georgia) may explain the shift in feeding of icefish from krill to fish. Furthermore, toothfish fishing decreases the availability of their young as food for icefish on the shelf.

Improved techniques for reading otolith microincrements along with otolith shapes and contours should enable us to better determine population structure, habitat connectivity and migration patterns for assessing stocks around Antarctic islands (Campana $\&$ Neilson 1985). Thus, we had 4 research objectives: (1) describe otolith morphometry and annual and locational variability; (2) determine the ages of $P$. georgianus individuals and identify the most suitable method(s) for use in stock assessments; (3) determine the age of $P$. georgianus individuals at maturity; (4) determine whether the $P$. georgianus occurring between South Georgia and the Antarctic Peninsula are composed of 1 population or multiple populations.

\section{MATERIALS AND METHODS}

\subsection{Fish collections}

Pseudochaenichthys georgianus specimens were collected during 17 summer cruises between the Antarctic Peninsula and South Georgia between 1976 and 1992 by the science teams of the RVs 'Profesor Siedlecki' and 'Profesor Bogucki' and the trawlers 'Gemini,' 'Sirius,' 'Taurus,' 'Carina,' 'Libra,' 'Neptun,' 'Hill Cove' and 'Falklands Protector.' Collections were made according to published recommendations (CCAMLR 2020) and under the control of the Scientific Committee for the Conservation of Antarctic Marine Living Resources (Agnew et al. 2017).

Investigations on the shelves were carried out at depths of $50-500 \mathrm{~m}$. The ice conditions limited the investigations to the austral summer, i.e. from November to March. The shelves were divided into horizontal statistical squares with 3 depth zones (50$150,151-250,251-500 \mathrm{~m}$ ) in which hauls from surface to bottom were carried out. The placing of the net hauls was determined randomly, and care was taken to ensure that control hauls were identical. Fish were caught for $\sim 30 \mathrm{~min}$ in a demersal net (P32/36) with horizontal and vertical openings of 17.5 and $4.5 \mathrm{~m}$, respectively, trawled at the given depth zone with an average speed of $6.5 \mathrm{~km} \mathrm{~h}^{-1}$ (3.5 knots). Pelagic hauls involved pelagic nets (WP 16/41). At each station, the total catch was estimated, and fish subsamples were sorted by species, weighed, measured to an accuracy of $1 \mathrm{~cm}$, sexed and assigned to 1 of 5 stages of maturity according to Everson et al. (1999). P. georgianus otoliths were removed for age determination. Larvae of 3-7 $\mathrm{cm}$ total length were present in the commercially trawled nets. According to CCAMLR (2020), net catchability of $100 \%$ and catchability coefficients of $q=1$ were assumed.

\subsection{Number of otoliths and fish taken for age structure estimation}

Detailed data were available for 600 specimens, 6-56 cm in total length, collected each year from 1977-1992 (36 282 fish in total). Because of time and cost limitations, the icefish were subsampled for var- 
ious aging approaches. Ages were estimated by daily micro-increment measurements of the 1987-1988 collection of 168 South Georgia otoliths, including 27 examined by scanning electron microscopy (SEM). The number of examined SEM images was limited by the quality of the recordings, cost and time required for their preparation, the number of SEM scans required for large otoliths and the limited SEM access by the lead author. Additional P. georgianus otoliths collected up to the year 1991 from South Georgia and the Antarctic Peninsula increased their number to 357 ; these were measured, weighed and examined by light microscopy for patterns in smallest daily micro-increments and otolith structure. In total, we studied 1712 otoliths to determine growth patterns in larval nuclei and shape changes along the transverse and median planes for $7 \mathrm{~cm}$ larvae to $62 \mathrm{~cm}$ adults caught around South Georgia and in waters of the Antarctic zone. We weighed 8235 otoliths (including those fractured during light-microscope slide preparation) to determine age groups from otolith mass.

Icefish age groups were estimated from body lengths and otolith features. These estimates were derived separately for fish from the South Georgia Shelf and the Antarctic Peninsula because of their differing otolith variability and range separations between each age group. Separating out the large population-level plasticity facilitated conclusions on the effects of climatic and environmental conditions. Estimated ages from otoliths may not completely characterize the age structure of an entire population. To achieve the characterization of the population's age structure, the equation $\mathrm{n}_{i j}=\mathrm{N}_{i} \mathrm{P}$ was used, where $\mathrm{N}_{i}$ is the number of fish in length class $i$ and $\mathrm{P}_{i j}=\mathrm{n}_{i j} \times \mathrm{n}_{i}^{-1}$, where $\mathrm{n}_{i}$ is the number of fish in the length class $i$ and $n_{i j}$ is the number of fish in the length class $i$ of age group $j$. The resulting age group distributions were further corrected by using Solver add-in in Excel to fit them to length frequency-mass curves by minimizing the sum of squared differences.

\subsection{Otolith preparation}

Each pair of otoliths was cleaned through immersion in Clorox until a white otolith surface was obtained, then rinsed with water, dried and weighed to an accuracy of $\pm 0.001 \mathrm{mg}$. Next, the otoliths were broken into halves across the centers of their nuclei and their maximum heights. One otolith half was mounted in plasticine with the broken surface uppermost. Other whole otoliths were embedded in epoxy resin and sectioned with a low speed stone saw through the nucleus along the frontal and median sagittal plane (Hecht 1987). Sectioned otoliths were ground on both sides using carborundum paper (no. 400-800) to reach their nuclei and then polished with a $1 \mu \mathrm{m}$ diamond compound by hand and a grinding machine under water to a thickness of $0.10-0.15 \mathrm{~mm}$. The polished sections were etched for 1-8 min with $7 \%$ EDTA (pH 7.35) and then cleaned with water and dried. The etched otolith surfaces were pressed into acetone-soaked acetate sheets that were dried for $30 \mathrm{~min}$ and then removed from the etched surfaces, yielding an acetate replica.

\subsection{Light microscope micro-increment counting}

Otolith micro-increments, annuli and other features were examined using light microscope (LM) transmitted and reflected light. Daily micro-increments were counted both by hand and automatically through use of a micro-densitometer (custom-built in the workshop of Gdańsk University; Traczyk 2015a) and a micro-digitizer (see Appendix). Under the micro-densitometer, the polished otolith sections, their acetate replicas and their photonegatives were moved stepwise in small intervals (1000 steps $\mathrm{mm}^{-1}$ ) across a narrow focused light beam along their growth radii. Profiles of growth patterns were recorded and measured as optical densities. The transmitted light intensities were recorded by a photocell and converted to digital values by an analog to digital converter and stored in a computer. Digital values of otolith density (after smoothing by moving averages) and daily micro-increments (opaque zones appearing as peaks of optical density) were automatically enumerated using Spectro Analyzer software (Drozdowski 1992).

In the micro-digitizer approach (see Appendix), otolith growth patterns from the acetate replicas and SEM coated surfaces were measured and digitized by LM. The positions of otolith daily micro-increments corresponding to micro-opaque zones were recorded. The number of daily micro-increments measured by LM covered the entire range of icefish total lengths. However, larval micro-increments can be overestimated by about 50-100 intersecting micro-increments as well as by sub-daily micro-increments (Geffen 1983). Therefore, daily micro-increments were counted from the nucleus edge (Radtke \& Hourigan 1990). This is important for $P$. georgianus because at the dorsal edges of otoliths of $7 \mathrm{~cm}$ larvae, otoliths develop a second primordium that grows in a different direction from the central primordium. 
Few otoliths from large icefish were available for use in micro-increment counting for 4 reasons: (1) Large icefish were few and only sporadically caught (Chojnacki \& Palczewski 1981, Traczyk \& MeyerRochow 2019). (2) Otoliths preserved in formalin are often damaged (Olsen 1955). (3) Large otoliths are often broken, leaving unusable otolith pieces (Chojnacki \& Palczewski 1981). (4) Otoliths of older $P$. georgianus often have dissolved or separated otolith edges that limit their use in later micro-increment analyses because their size and shape are altered as a response to rapid decreases in icefish mass after spawning.

\subsection{SEM micro-increment counting}

Etched otolith surfaces were coated with platinum and palladium in a sputter coater to a thickness of $2 \mathrm{~nm}$ under vacuum $\left(9.4 \times 10^{-8} \mathrm{Tr}\right)$ at an angle of $45^{\circ}$ (Geissinger 1976, Gabriel 1982). Coated otolith sections were individually mounted on aluminum stubs or in groups on microscope slides. Otoliths were examined under the SEM (FEI Quanta FEG 250) with the resultant electron emissions recorded on film, which allowed study of the otolith surface at a maximum resolution of $3 \mathrm{~nm}$. The data on daily microincrements obtained from selected light microscope slides were confirmed by the 27 SEM daily microincrement results for the presumptive age group of a fish.

Otoliths of $P$. georgianus are very poorly aragonized; therefore, after the removal of the aragonite crystals by EDTA, the remaining protein daily microincrement pattern is very weak. Under transmitted light, the arrangement creates alternating opaque and translucent bands that indicate the daily microincrements. However, under SEM high magnification, the daily pattern nearly disappears; therefore, the SEM may not give as clear a result as the LM. Nonetheless, with the SEM technique, an investigator automatically counting daily micro-increments with the micro-densitometer does not need several repetitions to determine otolith microstructures (Takács et al. 2016, Florin et al. 2018), whereas Kellermann at al. (2002) required 3 time-consuming blind counts.

\subsection{Validating daily micro-increments}

Recently, researchers have counted daily microincrements by LM to validate age groups of red- blooded fish (Morales-Nin \& Geffen 2015). We used 6 methods to validate daily micro-increments of 357 otoliths because any single interpretation often contains large errors, requires numerous confirmations and blind repetitions (Kellermann at al. 2002), possesses poor repeatability and can be highly subjective (Takács et al. 2016). Combining all 6 techniques aids in the accurate and precise determination of hatch dates, larval duration, migration to growth and feeding areas, and spawning dates, as well as fish age. Our 6 methods are summarized as follows: (1) We compared the daily micro-increments determined from the otoliths against their acetate replicas viewed by LM. (2) We conducted daily micro-increment counts common to all radii by using the multi-densitometer to automatically record and count peaks (dark zones) and large jumps from dark to light zones through the use of Spectro Analyzer software (Drozdowski 1992). (3) We compared daily micro-increments against the density profiles through the use of Image J software (Ferreira \& Rasband 2011, Kota 2016). We then determined the counts common to all radii and the smallest micro-increment by fitting sets of sinusoids that best explained the variability in density profiles with the smallest squared differences between density profiles and fitted sinusoids. (4) We automatically searched for daily micro-increments common to all radii seen with the LM by determining the relative displacement of their density profiles through the use of Image J software (Ferreira \& Rasband 2011, Kota 2016) until the squared differences between moving profiles indicated the first minimum. This determines the common smallest daily microincrement based on the closest daily period neighbors. (5) We used the micro-digitizer to record (using ACAD and BASIC) and count (using EXCEL) all daily micro-increments seen with the LM along the radii. (6) We confirmed the preceding 5 steps by a necessarily limited number of SEM examinations.

\subsection{Age determination from otolith measurements}

Otolith shapes were precisely digitized by using a micro-digitizer. The area, perimeter, height, rostral and ventral lengths and radius $\left(\mathrm{R}_{1-8}\right.$ on median sagittal and $R_{9-12}$ transverse planes) were measured. These parameters determine the shape descriptors for transverse and medial planes (Ferreira \& Rasband 2011). Otolith morphometry was carried out by photo documentation on technical millimeter paper according to Takács et al. (2016) and did not require blind repetitions. 
Otolith mass frequencies were checked for congruency among sampling dates and geographic locations of the trawls. The mean sizes of fish in each age group derived from analyses of multimodal otolith mass distributions (Glen 2015) were statistically compared (least significant difference test) and produced ages where they agreed. Variabilities in otolith masses were evaluated against cruise date and indicated that otolith masses of fish caught at the end of a cruise had about 30 daily micro-increments more than at the beginning of a cruise. Otolith masses were regressed against catch date, and samples from different stations (from South Georgia to the Antarctic Peninsula) were compared by box and whisker plots and tested by Tukey tests. No significant differences in masses indicate homogeneity and a unimodal population of icefish, whereas significant differences indicate heterogeneity and multimodal icefish populations or evolutionarily significant units. All statistical procedures were conducted in Statgraphics (1991) and Excel.

Age groups are represented by Roman numerals (Ralston \& Williams 1988). Otoliths of age group 0, caught in January, revealed 289 daily micro-increments ( 0.78 of a year), indicating that they hatched in the prior June and defining an age group with an average age of 0.78 . Consequently, we used 1.78, 2.78, 3.78, $4.78,5.78$ and 6.78 as nearest approximation of the 6 age groups, because $P$. georgianus has one seasonal spawning per year (Ghigliotti et al. 2017).

Otolith mass characterizes a population if its individual variability fits a lognormal distribution. For individuals from different populations, a bimodal distribution of otolith mass in the age group is generated. Total otolith mass was determined by weighing whole otoliths or all fragments of crushed otoliths. Age groups were also estimated from annual increments by grouping and ungrouping with tests and comparisons of homogeneous age groups. In some years, some larvae were occasionally noticed in the bycatch by Ślósarczyk (1983). The $7 \mathrm{~cm}$ long larvae (see Tables 1-3) collected for age estimation in the summer of 1988-1989 from bycatch were used to show a log-normal distribution of that age group, which for older age groups were maintained. However, the number of individuals in each generation decreased with age to few individuals and to 0 in the last age group of VI+ (Traczyk \& Meyer-Rochow 2019).

\section{RESULTS}

Natural age groups can be used to determine length frequency-mass (see also Traczyk \& MeyerRochow 2019) from estimated age groups with the equation $\left(\mathrm{n}_{i j}=\mathrm{N}_{i} \mathrm{P}_{i j}\right)$ and by minimizing their differences to empirical data. The resulting age group distributions were further corrected by using Solver software to fit them to length frequency-mass curves by minimizing the sum of squared differences. Larger fish, representing age groups IV, V and VI, were infrequently collected (Fig. 1, Tables 1 \& 2). Nonetheless, otolith morphology changes and total length differences indicate 7 different age classes $(0-\mathrm{VI})$, separated by yearly increases of $1 \mathrm{~mm}$ in otolith length for group 0-II fish and by collicula lengths for group III-VI fish (Fig. 1, Table 1). Similar yearly increases of otolith radii were obtained by Ralston \& Williams (1988) for tropical fish.

The otolith modes, ranges, box plots and Tukey test results for the trawls between the South Georgia Shelf and the Antarctic Peninsula were essentially the same (Fig. 1). For example, otolith modal masses for South Georgia age groups II, III, IV and V were $0.031,0.044,0.055$ and 0.063 and did not differ significantly from those for the Antarctic Peninsula (0.032, $0.043,0.052,0.067)$. The 7 otolith modes in gradation of otolith mass within 1 yr intervals fit lognormal and

Table 1. Age classes, fish lengths and otolith sizes of Pseudochaenichthys georgianus from South Georgia in 1987-1988. $\mathrm{O}_{\mathrm{r}} \mathrm{L}$ : otolith rostral length (main margin); $\overline{\mathrm{x}}$ : mean; s: standard deviation; M-S: median-sagittal

\begin{tabular}{|c|c|c|c|c|c|c|c|c|c|c|c|}
\hline \multirow{3}{*}{$\begin{array}{l}\text { Age } \\
\text { group } \\
\text { Years }\end{array}$} & \multirow{3}{*}{$\begin{array}{c}\text { Sample } \\
\text { size } \\
\mathrm{N}\end{array}$} & \multirow{2}{*}{\multicolumn{3}{|c|}{ Fish total length $(\mathrm{cm})$}} & \multicolumn{5}{|c|}{ Otolith dimensions (mm) } & \multicolumn{2}{|c|}{ Otolith cut area $\left(\mathrm{mm}^{2}\right)$} \\
\hline & & & & & \multirow{2}{*}{$\frac{\mathrm{O}_{\mathrm{r}} \mathrm{L}}{\overline{\mathrm{x}}}$} & \multicolumn{2}{|c|}{ Collicula length } & \multicolumn{2}{|c|}{ Height } & \multirow{2}{*}{$\begin{array}{l}\mathrm{M}-\mathrm{S} \\
\overline{\mathrm{x}}\end{array}$} & \multirow{2}{*}{$\begin{array}{c}\text { Transverse } \\
\overline{\mathrm{x}}\end{array}$} \\
\hline & & Range & $\overline{\mathrm{x}}$ & $\mathrm{s}$ & & $\overline{\mathrm{x}}$ & $\mathrm{s}$ & $\overline{\mathrm{x}}$ & $\mathrm{s}$ & & \\
\hline 0 & 171 & 68 & 7.4 & 0.47 & 1.1 & 0.66 & 0.33 & 1.84 & 0.35 & 1.9 & 0.93 \\
\hline I & 64 & 1423 & 20.5 & 2.18 & 2.7 & 2.09 & 0.24 & 3.18 & 0.22 & 4.8 & 2.86 \\
\hline II & 167 & 2738 & 33.9 & 3.68 & 3.4 & 3.19 & 0.44 & 4.19 & 0.22 & 11.07 & 5.94 \\
\hline III & 207 & $42 \quad 48$ & 44.1 & 2.71 & 3.6 & 4.04 & 0.41 & 4.94 & 0.19 & 15.28 & 8.25 \\
\hline IV & 96 & $47 \quad 52$ & 49.7 & 2.81 & 3.8 & 4.88 & 0.36 & 5.32 & 0.23 & 18.38 & 10.15 \\
\hline V & 43 & $47 \quad 53$ & 50.9 & 2.48 & 4 & 5.85 & 0.32 & 5.46 & 0.54 & 20.83 & 11.79 \\
\hline VI & 6 & 5154 & 52.6 & 2.22 & 4.1 & 6.7 & 0.1 & 5.5 & 0.19 & 21.86 & 13.94 \\
\hline
\end{tabular}


Table 2. Age classes, fish lengths, body mass, otolith masses and number of daily micro-increments in otoliths of Pseudochaenichthys georgianus from South Georgia in 1987-1988. LM: light microscope; $\overline{\mathrm{x}}$ : mean; s: standard deviation; \pm CL: confidence limits

\begin{tabular}{|c|c|c|c|c|c|c|c|c|c|c|c|}
\hline \multirow{3}{*}{$\begin{array}{l}\text { Age } \\
\text { group } \\
\text { Years } \\
0\end{array}$} & \multirow{3}{*}{$\begin{array}{c}\begin{array}{c}\text { Sample } \\
\text { size } \\
\mathrm{N}\end{array} \\
100\end{array}$} & \multirow{3}{*}{$\begin{array}{c}\text { Total } \\
\text { length }(\mathrm{cm}) \\
\overline{\overline{\mathrm{x}}} \\
7.9\end{array}$} & \multicolumn{2}{|c|}{ Body mass (g) } & \multicolumn{4}{|c|}{$\begin{array}{l}\text { Number of daily micro-increments } \\
\text { in LM along otolith dorsal radius }\end{array}$} & \multicolumn{3}{|c|}{-Otolith mass $(\mathrm{g})$} \\
\hline & & & \multirow{2}{*}{$\begin{array}{c}\overline{\mathrm{x}} \\
1.01\end{array}$} & \multirow{2}{*}{$\frac{\mathrm{s}}{0.77}$} & \multicolumn{2}{|c|}{ Range } & \multirow{2}{*}{$\begin{array}{c}\overline{\mathrm{x}} \\
286\end{array}$} & \multirow{2}{*}{$\begin{array}{c}\mathrm{s} \\
35.5\end{array}$} & \multirow{2}{*}{$\begin{array}{c}\overline{\mathrm{x}} \\
0.0018\end{array}$} & \multirow{2}{*}{$\begin{array}{c}\mathrm{s} \\
0.0006\end{array}$} & \multirow{2}{*}{$\begin{array}{c} \pm \mathrm{CL} \\
0.0005\end{array}$} \\
\hline & & & & & 230 & 340 & & & & & \\
\hline I & 20 & 22.6 & 41.1 & 15.7 & 587 & 654 & 612 & 43.9 & 0.0157 & 0.0020 & 0.0007 \\
\hline II & 15 & 35.6 & 348.3 & 171.8 & 957 & 1070 & 1001 & 90.4 & 0.0290 & 0.0029 & 0.0006 \\
\hline III & 13 & 45 & 910.9 & 202.5 & 1324 & 1429 & 1387 & 29 & 0.0416 & 0.0034 & 0.0007 \\
\hline IV & 10 & 50.7 & 1242.2 & 186.8 & 1683 & 1801 & 1739 & 88.6 & 0.0538 & 0.0027 & 0.0009 \\
\hline $\mathrm{V}$ & 6 & 50.3 & 1380.4 & 185.3 & 2060 & 2170 & 2118 & 106.1 & 0.0676 & 0.0035 & 0.0014 \\
\hline VI & 4 & 54 & 1540 & 207.5 & 2420 & 2432 & 2426 & 8.5 & 0.0753 & 0.0022 & 0.0022 \\
\hline
\end{tabular}

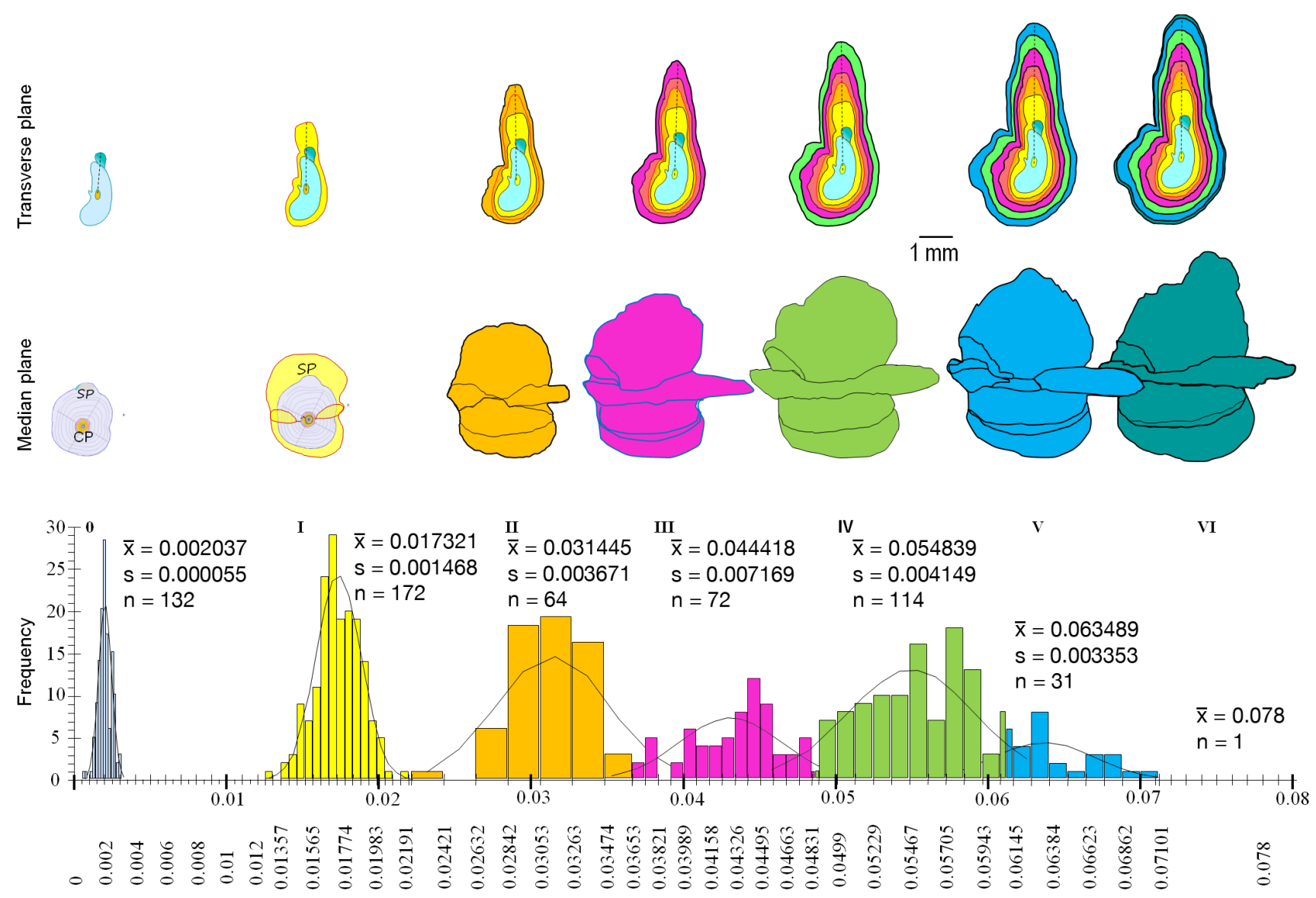

Fig. 1. Otolith shape changes in transverse and median-sagittal planes showing the progression of otolith mass histograms with superimposed normal plots of the fitted distributions and normal distributions $N(\overline{\mathrm{x}}, \mathrm{s})$ of total body length associated with year classes 0-VI of Pseudochaenichthys georgianus from South Georgia in 1989-1990, where $\overline{\mathrm{x}}$ : mean, s: standard deviation. Six year classes in otolith mass $(\mathrm{g})$ with lognormal and normal distributions were grouped by very small modes of neighbor distances within each age class 0 (0.0000205 g), I (0.0000508 g), II (0.0001978 g), III (0.0001483 g), IV (0.0001128 g) and V $(0.0003429 \mathrm{~g})$ and large distances between classes (0-I: $0.0089 \mathrm{~g}$; I-II: 0,0042 g; II-III: $0.00079 \mathrm{~g}$; III-IV: $0.00049 \mathrm{~g}$; IV-V: $0.00045 \mathrm{~g}$; V-VI: $0.007116 \mathrm{~g})$. Average otolith mass of females $(0.041 \mathrm{~g})$ was higher than that of males $(0.031 \mathrm{~g})$, which explains some lapses in the histograms from the normal distributions of populations for age groups III, IV and V (mature fish). CP: central primordium, SP: second primordium 
normal distributions (Peterson 1981) (Fig. 1), further indicating little regional variability in otolith mass within each age class from South Georgia to the Antarctic Peninsula.

There were no significant differences between average mass of left and right otoliths, and the LM
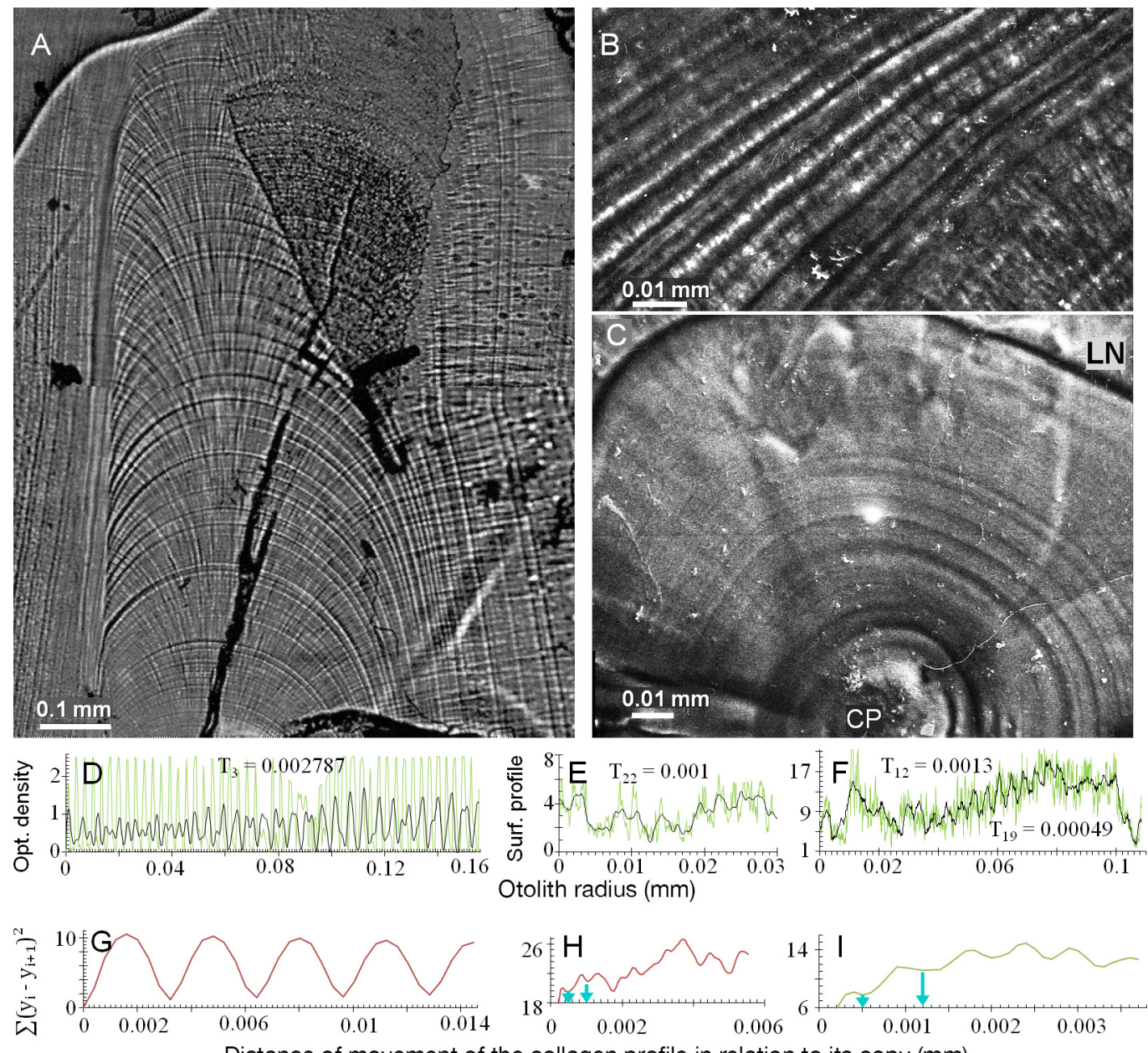

Fig. 2. (A) Photograph of the acetate replica from the surface of the Pseudochaenichthys georgianus otolith (transverse section) used for daily counts. (B) Micro-increments between the calcified central primordium and the highly calcified otolith edge of a $50 \mathrm{~cm}$ total length $P$. georgianus as shown via SEM. LN: larval nucleus. (C) Micro-increments around the weakly calcified central primordium (CP). (D) Harmony analysis was fitted to the profile of collagen optical density fluctuation on the acetate replica by using the sum of $n$ harmonics following Salim \& Thekra (2009): $\sum n\left\{\left[A_{n} \sin \left(2 \pi \cdot T_{n}{ }^{-1}\right) \cdot x+\varphi_{n}\right]+C_{n}\right\}$, where $A_{n}=$ amplitudes in fluctuation density of collagen, $\mathrm{T}_{\mathrm{n}}=$ distance of time increment $(\mathrm{mm}), \varphi_{\mathrm{n}}=$ phases, $x=$ distance along (horizontal) otolith growth radius, $\mathrm{C}_{\mathrm{n}}=$ the base of sinusoidal collagen density oscillation with minimum squared differences between them corresponding to the smallest basic daily period (i.e. $\mathrm{T}_{3}=0.0028 \mathrm{~mm}$ ). (E) Variable growth of micro-increments across local changes of pressure with compressed basic period: $T_{22}=0.001 \mathrm{~mm}$. (F) A larval otolith with a radius of $0.107 \mathrm{~mm}$ may have 83 daily micro-increments, fitting daily units of 21 periodic functions. $(\mathrm{D}, \mathrm{E}, \mathrm{F})$ Green line = empirical data, profile of collagen density reflected by otolith surface of SEM; black line = fitted sum of $n$ harmony equations to empirical data. Direction of measurements from otolith center $(0 \mathrm{~mm})$ to the nucleus edge $(0.15 \mathrm{~mm})$. (G) Tests confirm that the average of 100 adjacent micro-increments based on acetate replica counts has a periodicity of $0.0032 \mathrm{~mm}$. (H) Survey of daily units of adult otolith growth (distance unit between surface ridges) to locate the first smaller distance between ridges that replicate along overall otolith growth radius. It is obtained by the minimum of the sum of squared differences between all close neighbour ridges. First minimum (at 0.0005 mm; first blue arrow) indicates many daily increments which are locally compressed (narrow) to smaller width indicative of high pressure areas. Second blue arrow highlights wider daily increments in the collagen profile. (I) The first minimum (0.0005 mm; first blue arrow) in the larval nucleus suggests the presence of sub-daily micro-increments. The next micro-increment at 0.0012 mm wide (second blue arrow) is thought to be a daily increment 
had similar median surfaces $\left(357 \mathrm{~mm}^{2}, \mathrm{~s}=56 \mathrm{~mm}^{2}\right)$ and numbers of daily micro-increments (mean $45, \mathrm{~s}=$ 0.68). This indicates constant growth rates in the egg and the same time of hatching after fertilization during those years.

Distributional normality of total lengths and a lognormal relation for otolith masses began with age-0 icefish larvae (Fig. 1). Individuals of separate age groups were separated from individuals of younger or older age groups by a $\geq 10$ times larger distance than the within-group variability of an age group. These results are further supported by the statistical descriptions of the otolith masses and daily microincrements of the age groups collected from South Georgia in 1987-1988 (Tables 2 \& 3).

Parameters of normal frequency were fitted to empirical data of total length and otolith mass (Fig. 1) and radius from Tables $1 \& 3$. Tested graphically, they confirmed the separation of all age groups (Figs. 1, 5 $\& 6)$. The lognormal distribution of otolith mass of older age groups is less ambiguous, and the separation index between age groups is sufficiently large for otolith mass (Fig. 5). Otolith mass of all age groups resulted in little standard deviation (Table 2,
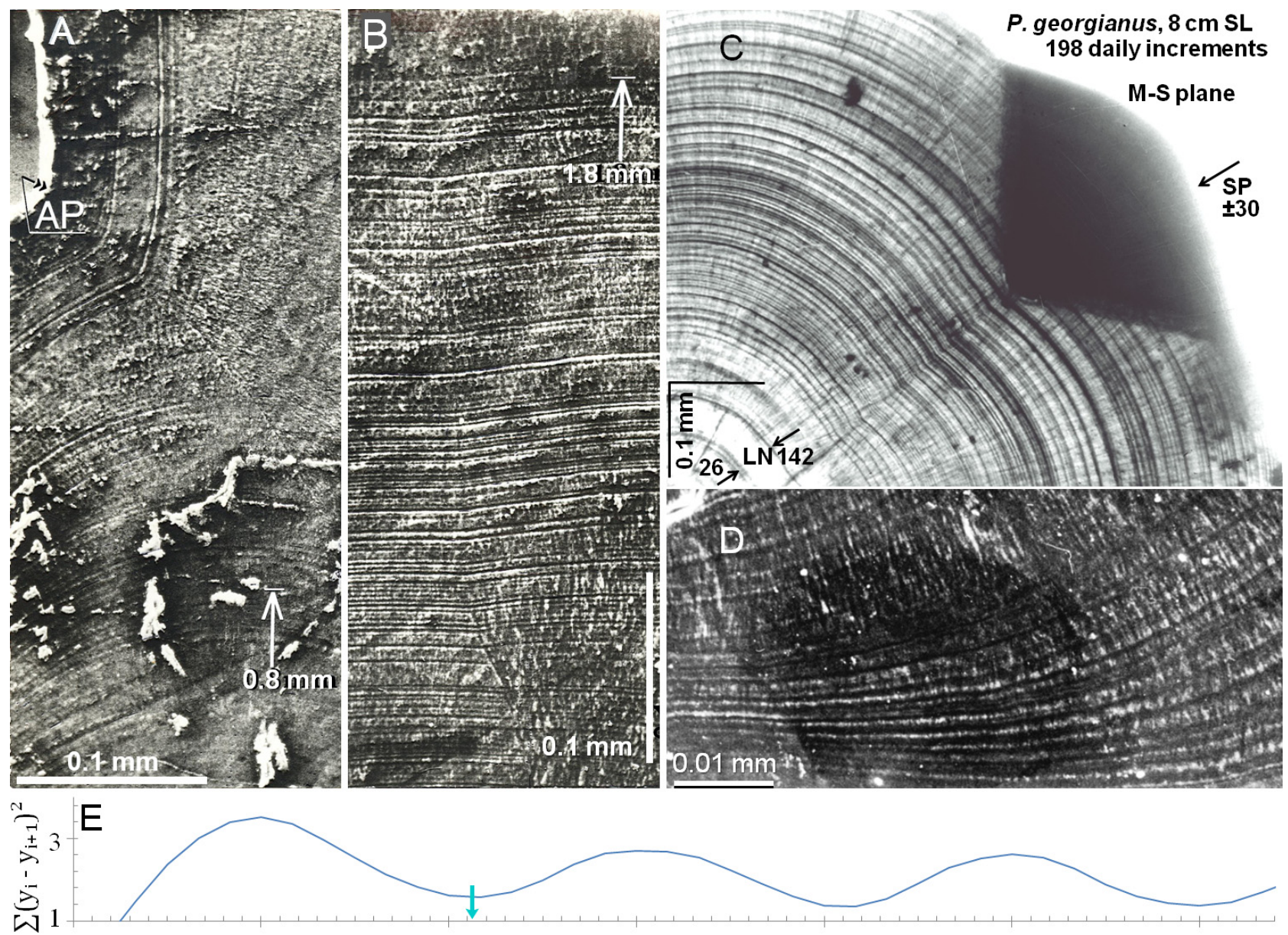

0
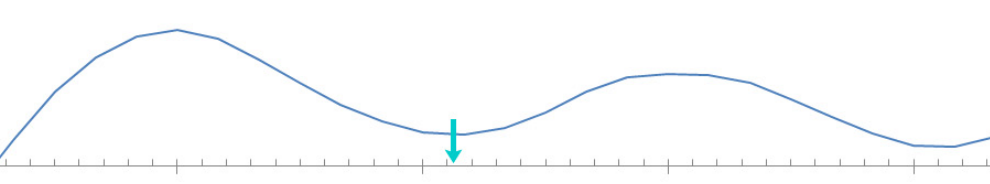

0.001

0.0015

0.002
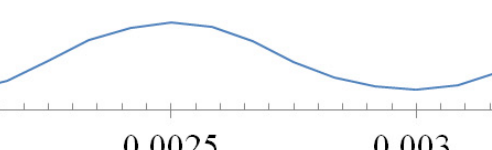

Distance of movement of the collagen profile in relation to its copy $(\mathrm{mm})$

Fig. 3. (A) Connections between daily micro-increments originating from the central primordium (CP, not shown) and from the additional primordium (AP) in a portion of an SEM micrograph. $0.8 \mathrm{~mm}$ is the distance from the CP. (B) Narrow increments can be followed for a distance of up to $1.8 \mathrm{~mm}$ from the CP in an SEM micrograph. (C) Micro-increments from the median-sagittal (M-S) section showing the second primordium (SP) and larval nucleus (LN) as shown by light microscopy: $26=$ number of daily increments from otolith center to wider increment inside nucleus ( $26 \mathrm{~d}$ sequence); $142=$ number of daily increments from otolith nucleus to start of secondary primordium (new center of otolith growth) $\pm 30=$ number of daily increments from secondary primordium (new center of otolith growth that propagates in different directions (see Fig. 4) that integrates with daily increments from the CP. The exact number cannot be determined because of the black zone. SL: standard length. (D) SEM micrograph showing numerous daily micro-increments squeezed between wider increments, causing problems in counting them. (E) Parallel dislocation of profile of above collagen oscillation (D) in relation to its digital copy reveals that the smallest daily total comparable compressed period across the otolith is equal to $0.00106 \mathrm{~mm}$ (blue arrow) 

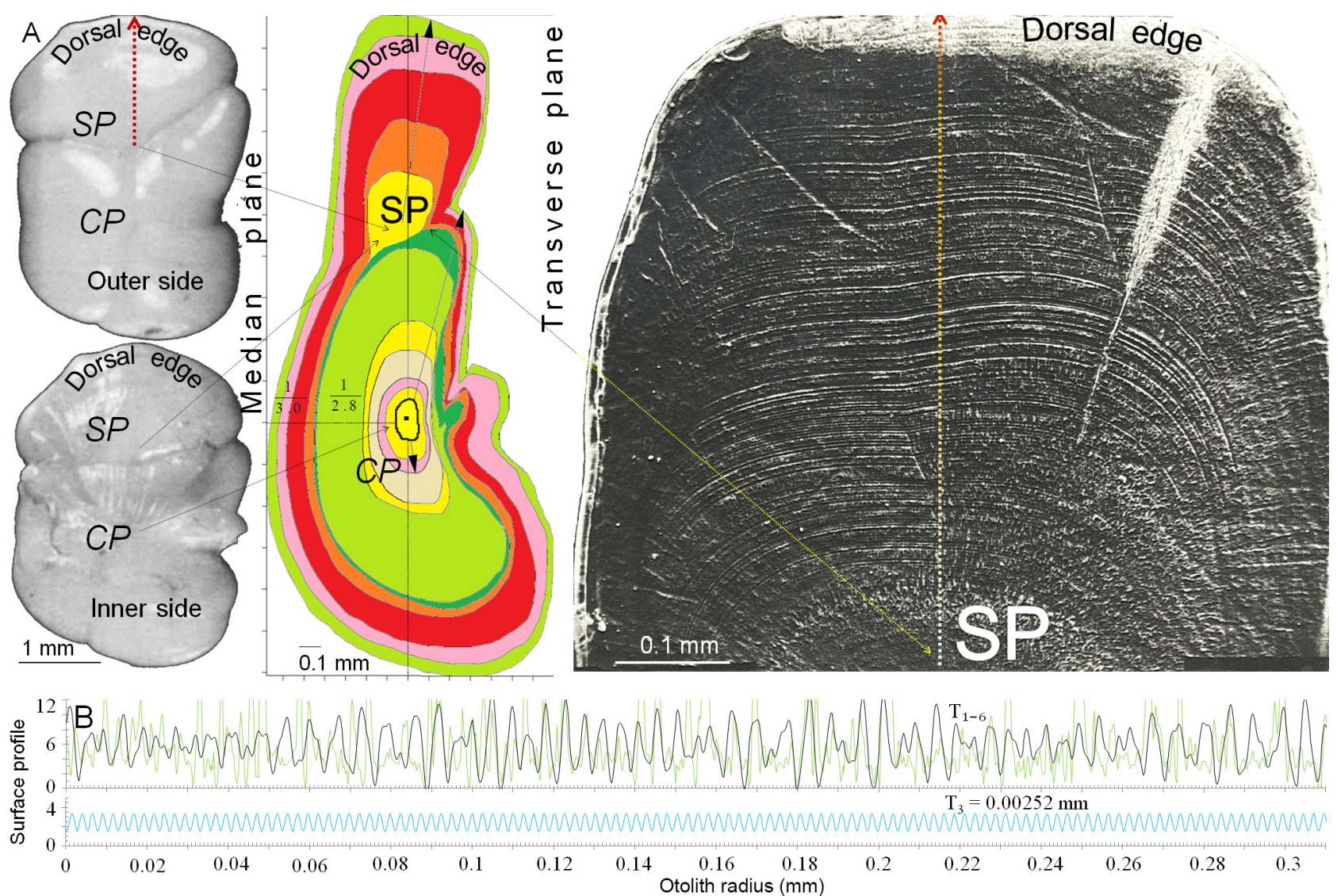

$A_{1-6}=11.3,21.5,-9.4,17.4,12.2,21.6 ; \varphi_{1-6}=1.1,6.3,0.6,1.5,5.3,7.3 ; T_{1-6}=0.00437,0.00647,0.00252,0.0061,0.00465,0.00455 ; C_{1-6}=6.8,6.8,24.8,6.8,6.83,6.84$

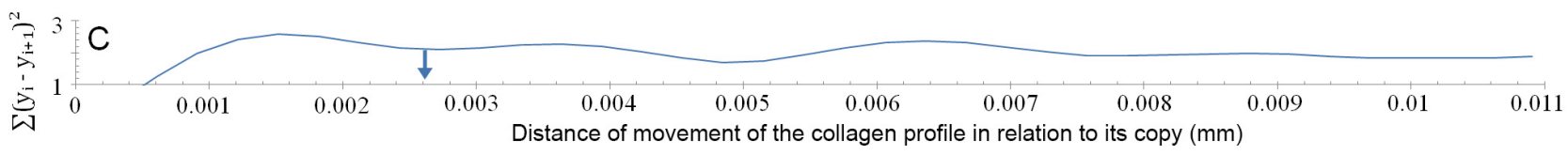

Fig. 4. (A) Second primordium (SP) and central primordium (CP) characterized by increased flattening (left) and age group I micro-increments along the dorsal edge of the otolith as depicted in the SEM micrograph on the right. Fractions represent flattening coefficient of otolith width. (B) Harmony analysis of the growth of micro-increments from the SP based on the smallest basic period: $\mathrm{T}_{3}=0.0025 \mathrm{~mm}$ (see Fig. $2 \mathrm{D}$ for more detailed explanation of harmony analysis). Green line $=$ empirical data, profile of collagen quantity fluctuation on otolith surface; black line = fitted sum of 6 harmony equations to empirical data with 6 periods $\left(\mathrm{T}_{1-6}\right)$; blue line $=$ daily periodic equation (base oscillation) that is the third component (with period $\mathrm{T}_{3}=0.00252 \mathrm{~mm}$ ) of 6 fitted harmony equations. $\mathrm{A}_{1-6}=6$ amplitudes of 6 harmony equations fitted to empirical data; $\varphi_{1-6}=6$ phases of 6 harmony equations fitted to empirical data; $\mathrm{T}_{1-6}=6$ periods of 6 harmony equations fitted to empirical data; $\mathrm{C}_{1-6}=6$ constant values (base line) of 6 harmony equations fitted to empirical data. (C) Tests confirm that the average of adjacent micro-increments is a period around $0.00252 \mathrm{~mm}$. Arrow shows results of test of existence of smallest daily period common for all age groups determined by the minimum of sum of squared differences (minimum $y$-value). For more details, see Fig. 2G,H,I

Fig. 1) and the chance of outliers being present was lower than $\alpha=0.05$ (Fig. 5). Differences in otolith mass between age groups of adult fish were on the order of $0.008 \mathrm{~g}$, but the variation within age groups was no more than $0.000021 \mathrm{~g}$ in age group 0 and 0.00034 in older age groups (Fig. 1). This confirms that age groups can reliably be separated on the basis of otolith mass and that individuals of the same age group share the same birth year.

We considered directional growth changes of the otolith radius (Fig. 6A), initially to the dorsal edge until growth stopped in that direction (Fig. 6B) and then to the anterior edge (Fig. 1). Knowing the widths of the daily micro-increments (Figs. 2D-I \& 4B,C), it was possible to determine the age in days for a given otolith mass (Fig. 5) and thus age group from the lengths of the radii (Fig. 6). This provided an almost linear relationship between otolith mass and number of daily increments according to the equation:

$$
\begin{aligned}
\text { Age }[\text { Days }]= & \exp \left[12.0096\left(3 / 4 \mathrm{OM}[\mathrm{g}] \times 10^{-5} \times \pi^{-1}\right)^{1 / 3}\right. \\
& +4.51812]
\end{aligned}
$$


Table 3. Age classes, fish lengths, growth of otolith dorsal radius, width and number of daily micro-increments and otolith shape descriptors of Pseudochaenichthys georgianus from South Georgia in 1987-1988. SEM: scanning electron microscope; $\Delta$ : increments for appropriate age group $;-\Delta_{\mathrm{SP}}$ : increments in different direction from second primordium; $\overline{\mathrm{x}}: \mathrm{mean}_{i} \mathrm{D}_{1}\left(\mathrm{D}_{2}\right)$ : smallest (second smallest) daily micro-increment width (base); Roun: roundness ratio; $\mathrm{R}_{\mathrm{T}-\mathrm{M}}$ : roundness of transverse with median planes; Circ: circularity ratio; Elon: elongation ratio; Maj (Min): major (minor) axes (mm) of fitted ellipse

\begin{tabular}{|c|c|c|c|c|c|c|c|c|c|c|c|c|c|c|c|}
\hline \multirow{3}{*}{$\begin{array}{l}\text { Age } \\
\text { group } \\
\text { Years }\end{array}$} & \multirow{3}{*}{$\begin{array}{c}\text { Total } \\
\text { length }(\mathrm{cm}) \\
\overline{\mathrm{x}}\end{array}$} & \multirow{2}{*}{\multicolumn{3}{|c|}{$\begin{array}{l}\text { Growth of otolith at } \\
\text { dorsal radius (mm) }\end{array}$}} & \multicolumn{5}{|c|}{ Daily micro-increments in SEM } & \multicolumn{6}{|c|}{ Otolith shape descriptors, median plane } \\
\hline & & & & & Width & $(\mathrm{mm})$ & & Jumb & & \multirow{2}{*}{$\underset{\overline{\mathrm{x}}}{\mathrm{Roun}}$} & \multirow{2}{*}{$\frac{\mathrm{R}_{\mathrm{T}-\mathrm{M}}}{\overline{\mathrm{x}}}$} & \multirow{2}{*}{$\begin{array}{c}\text { Circ } \\
\overline{\mathrm{x}}\end{array}$} & \multirow{2}{*}{$\begin{array}{l}\text { Elon } \\
\overline{\mathrm{x}}\end{array}$} & \multirow{2}{*}{$\begin{array}{l}\text { Maj } \\
\overline{\mathrm{x}}\end{array}$} & \multirow{2}{*}{$\underset{\overline{\mathrm{x}}}{\operatorname{Min}}$} \\
\hline & & $\overline{\mathrm{x}}$ & $\Delta$ & $-\Delta_{\mathrm{SP}}$ & $\mathrm{D}_{1}$ & $\mathrm{D}_{2}$ & $\overline{\mathrm{x}}$ & $\Delta$ & $-\Delta_{\mathrm{SP}}$ & & & & & & \\
\hline 0 & 7.9 & 0.943 & 0.836 & 0.258 & 0.0019 & 0.0025 & 302 & 334 & 103 & 0.678 & 0.75 & 0.77 & 46.6 & 1.70 & 0.73 \\
\hline I & 22.6 & 1.94 & 0.904 & & 0.0024 & 0.0027 & 637 & 335 & & 0.551 & 0.60 & 0.694 & 76.7 & 3.21 & 1.14 \\
\hline II & 35.6 & 3.21 & 1.2 & 0.1 & 0.0027 & 0.0032 & 983 & 396 & 50 & 0.565 & 0.80 & 0.665 & 82.7 & 4.31 & 1.56 \\
\hline III & 45 & 3.74 & 0.53 & & 0.0011 & 0.0015 & 1336 & 353 & & 0.612 & 0.79 & 0.653 & 74.8 & 5.02 & 1.90 \\
\hline IV & 50.7 & 3.9 & 0.16 & & 0.0004 & 0.0019 & 1691 & 355 & & 0.579 & 0.83 & 0.642 & 74.1 & 5.57 & 2.32 \\
\hline $\mathrm{V}$ & 50.3 & 4.1 & 0.2 & & 0.0006 & 0.0011 & 2024 & 333 & & 0.633 & 0.89 & 0.597 & 56.4 & 6.12 & 2.73 \\
\hline VI & 54 & 4.35 & 0.25 & & & 0.0007 & 2381 & 357 & & 0.753 & 0.92 & & & & \\
\hline
\end{tabular}
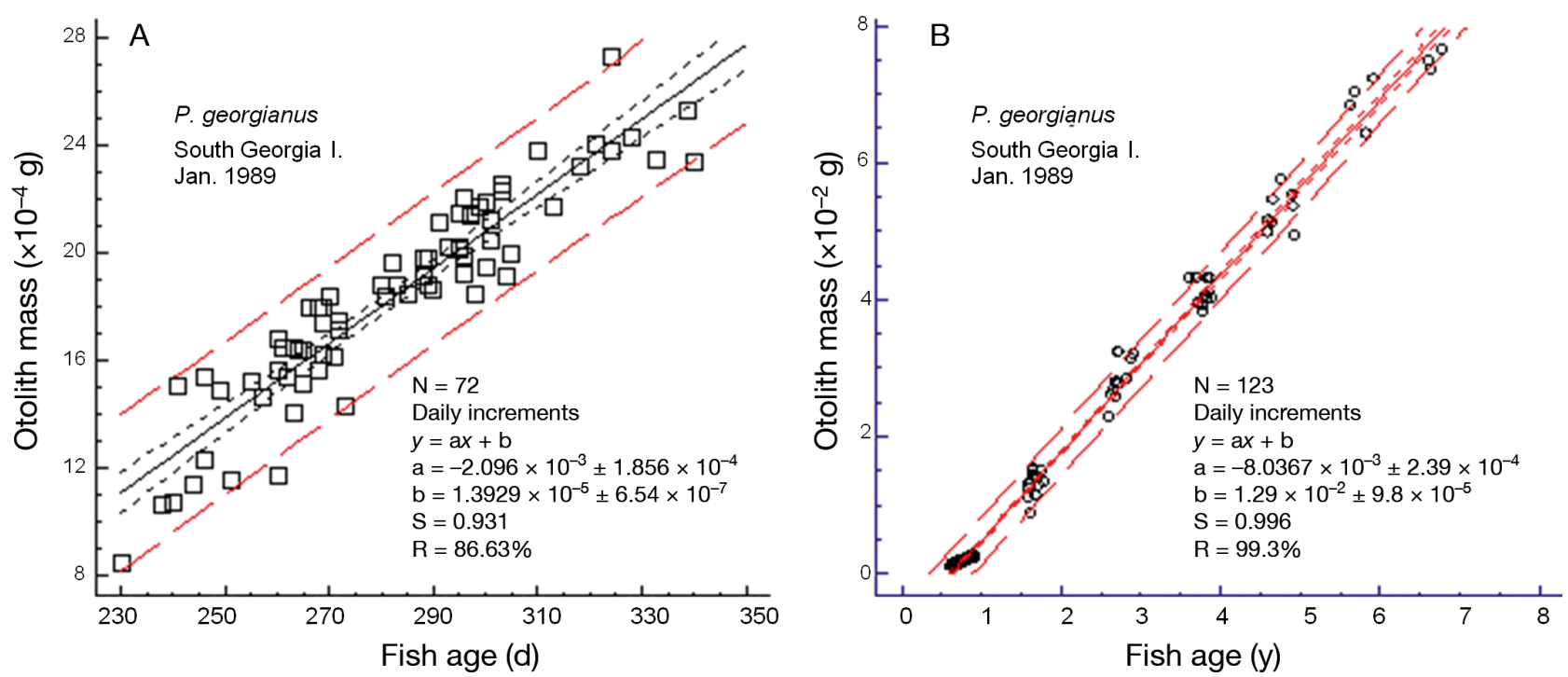

Fig. 5. Estimated ages of Pseudochaenichthys georgianus (A) juveniles and (B) adults from South Georgia based on otolith mass. Solid line: regression line; dashed line: 95 or $99 \%$ confidence limits for regression line; dotted lines: prediction limits

$$
\text { Age }[\text { Days }]=27416.398 \times \mathrm{OM}[\mathrm{g}]+131.245
$$

(Fig. 6) where OM is otolith mass.

Similarly, the expected curvilinear relationship between otolith radii and age group is described by a fitted von Bertalanffy equation:

$$
\text { Age }=-689.655 \times \ln (1-0.237 \times R)-141.7
$$

where $\mathrm{R}$ is otolith radius.

Thus, the larval otolith radius and that of young and immature adults of Pseudochaenichthys georgianus increased on average by $1.1 \mathrm{~mm} \mathrm{yr}^{-1}$ (Figs. 1, 3A,B, $4 \mathrm{~A}, 6$, Tables $1 \& 3$ ), whereas total body length increased by about $10 \mathrm{~cm} \mathrm{yr}^{-1}$ and body mass by about $310 \mathrm{~g} \mathrm{yr}^{-1}$. For older mature icefish, growth of both otolith radius and total length slowed to near 0 (Fig. 6B). On the other hand, both otolith mass and body mass usually maintained their previous growth rates (Table 3). In older mature icefish, growth of the anterior radius $R_{3}$ increased and produced greater otolith roundness (Table 1, Fig. 1) and together with $\mathrm{R}_{9}$ characterized age groups IV, V and VI (Fig. 1), whereas $\mathrm{R}_{9}$ alone did not (Fig. 6B).

\subsection{Age group 0}

Otoliths were light (0.0018 g), disc-shaped, almost circular on the median plane and kidney-shaped on the transverse plane, with small collicula on the inner side (Fig. 1, Table 2). There were 230-340 microincrements under the LM and 334 under the SEM by January in fish ranging from $6-8 \mathrm{~cm}$. We concluded that $6 \mathrm{~cm}$ long larvae averaging 250 daily micro- 

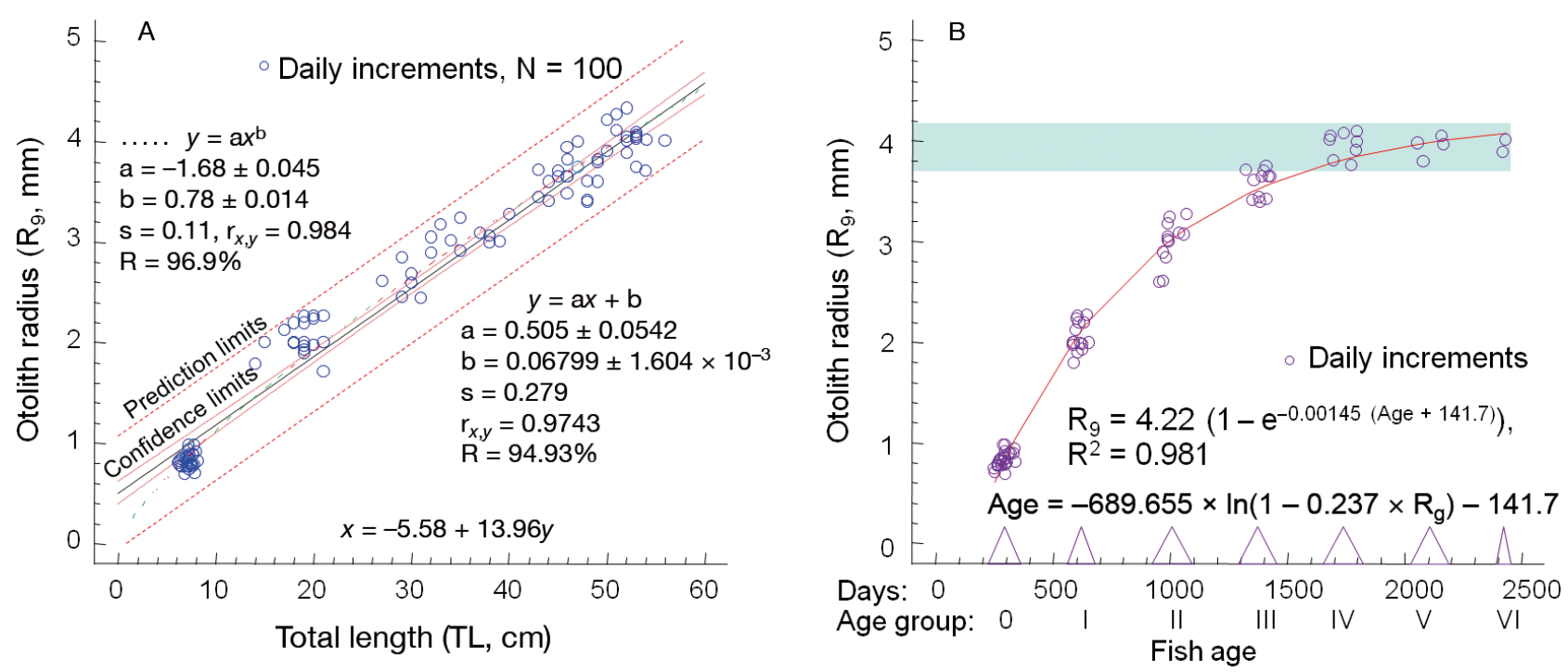

Fig. 6. (A) Linear and multiplicative relationship between otolith radius and total length for Pseudochaenichthys georgianus off South Georgia Island. (B) Relationship of age to otolith radius for P. georgianus aged by back-calculated data and fitted to the von Bertalanffy equation. $a, b$ : equation coefficients and their confidence limits; $s$ : standard deviation, $\mathrm{r}_{x y}$ : correlation coefficient; R: coefficient of determination. Shading in panel B indicates otolith radii that may share individuals of different age groups; triangles along $x$-axis indicate age groups

increments were $<1 \mathrm{yr}$ old. Near the otolith edge were 40-60 relatively wide daily micro-increments (signifying faster growth), followed by narrower daily micro-increments in the second primordium (Figs. 3C \& 4). This age group in the January fishery was not preceded by a smaller group of fish. Extending this to a 12 mo period, fish growth was about $14 \mathrm{~cm}$ and otolith growth was $0.0013 \mathrm{~g}$ and $1 \mathrm{~mm} \mathrm{yr}^{-1}$ (Fig. 1, Tables 1 \& 2).

\subsection{Age group I}

Otoliths were heavier $(0.01567 \mathrm{~g})$, larger $\left(5 \mathrm{~mm}^{2}\right)$ and substantially higher and flatter than those of age-0 fish (Fig. 1, Tables 1-3). We counted a total of 587-654 daily micro-increments under the LM and 335 daily increments beyond age-0 fish via SEM, indicating 637 total days of life $(<2 \mathrm{yr})$. Group I individuals averaged $20.5 \mathrm{~cm}$ total length (Fig. 6A), ranging from $14-23 \mathrm{~cm}$. The greater otolith heights are associated with fish living below $400 \mathrm{~m}$ and migrating vertically.

\subsection{Age group II}

Otoliths were heavier $(0.029 \mathrm{~g})$ and larger $\left(11 \mathrm{~mm}^{2}\right)$ than for fish in age group I (Fig. 1, Tables 1 \& 2). A total of 957-1070 micro-increments were measured by LM and 396 by SEM, indicating an average age of $983 \mathrm{~d}(\sim 2.7 \mathrm{yr})$. Average icefish total length was $33.9 \mathrm{~cm}$, ranging from $27-38 \mathrm{~cm}$ (Fig. 6A).

\subsection{Age group III}

Otoliths were heavier $(0.042 \mathrm{~g})$ and larger $\left(15 \mathrm{~mm}^{2}\right)$ and their collicula lengths were markedly greater than for group II fish (Fig. 1, Tables 1 \& 2). LM measurements indicated 1324-1429 daily micro-increments and 353 for that year with SEM, indicating an average age of $1336 \mathrm{~d}$ ( $\sim 3.6 \mathrm{yr})$. Average icefish total length was $44.1 \mathrm{~cm}$, varying between 42 and $48 \mathrm{~cm}$ (Fig. 6A).

\subsection{Age group IV}

Otoliths were heavier $(0.054 \mathrm{~g})$ and larger $\left(18 \mathrm{~mm}^{2}\right)$ with further elongated collicula compared to group III fish (Fig. 1, Tables 1 \& 2). LM measurements revealed 1683-1801 daily micro-increments and an average age of $1696 \mathrm{~d}$ ( 4.6 yr), which were confirmed by 1691 micro-increments in SEM measurements. Fish total lengths averaged $49.7 \mathrm{~cm}$ and ranged from $47-52 \mathrm{~cm}$ (Fig. 6A).

\subsection{Age group V}

Average otolith mass $(0.068 \mathrm{~g})$ and area $\left(21 \mathrm{~mm}^{2}\right)$ further increased compared to fish from age group 
IV, and the collicula remained elongated (Fig. 1, Table 1). LM examination indicated 2060-2170 microincrements and narrowing widths of daily microincrements $(0.0006 \mathrm{~mm})$; SEM measurements indicated a mean age of $2024 \mathrm{~d}$ ( $5.5 \mathrm{yr}$ ). Fish total lengths averaged $50.9 \mathrm{~cm}$ and ranged from $47-53 \mathrm{~cm}$ (Fig. 6A).

\subsection{Age group VI}

Icefish of this age group averaged $53.5 \mathrm{~cm}$ in total length and ranged from 51-56 cm (Fig. 6A). Average otolith mass $(0.075 \mathrm{~g})$ and area $\left(22 \mathrm{~mm}^{2}\right)$ increased relatively little compared to group V fish (Fig. 1, Table 1). The widths of daily micro-increments $(0.0007 \mathrm{~mm})$ at the otolith dorsal edge and the increased collicula lengths (along both vertical and horizontal otolith axes) continued in relation to the sensory role of the otolith. The number of daily micro-increments measured by LM was 2420-2432, indicating an age of $2426 \mathrm{~d}(6+\mathrm{yr})$, which was confirmed by SEM counts of 2381 micro-increments.

\section{DISCUSSION}

\subsection{Methodology}

Information on the age structures and biomass changes of icefish is needed for a greater understanding and prevention of the negative effects of climate change. Such information is used to track and study inter-species relationships associated with environmental oscillations and global warming (Sahrhage 1988, Traczyk et al. 2020). Chronologically recorded collections of otoliths, especially those of icefish, have been used for age analyses and fish stock assessment in Antarctica since the 1970s (May et al. 1979, Rosenberg \& Beddington 1987, Kock 1989). Otoliths are very powerful indicators (Morales-Nin \& Geffen 2015) for deciphering environmental changes from the distant past to the present (Hecht 1987, Schwarzhans \& Carnevale 2017). The shapes of otoliths can be used to reveal population structure, migration patterns, stock recognition and adaptations to different or changing habitats (Campana \& Neilson 1985).

Previous estimates of icefish age groups were based on otolith annual ring estimates, which suggested 12+ classes (Chojnacki \& Palczewski 1981), but our statistical tests indicated only 6 age classes (Fig. 1, Table 1). Also, earlier otolith measurements were made in a single direction (Mucha 1980, Chojnacki \& Palczewski 1981), which ignored changes in otolith shape and micro-increment widths that cooccur with changes in behavior, growth rate and age at maturity.

Unfortunately, almost all earlier collected otoliths of Pseudochaenichthys georgianus were either crushed, broken, burnt (Chojnacki \& Palczewski 1981) or unsuccessfully assessed by traditional LM methods of estimating age (Mucha 1980) with unacceptably large errors (Takács et al. 2016). A few otoliths were prepared by Florin et al. (2018) for daily microincrement counts via LM and SEM. Their LM images showed daily micro-increments, whose smallest widths were determined by Kellermann et al. (2002) as $0.00038-0.00075 \mathrm{~mm}$ and even less than $0.0002 \mathrm{~mm}$ by Radtke (1990). Average widths of daily microincrements $(0.0014-0.0023 \mathrm{~mm})$ were reported for Champsocephalus gunnari larvae by Traczyk (2015b). Accurate and precise counting to minimize sampling noise caused by crevices, cracks, absence or additional undersurface increments of $>2000$ daily micro-increments per otolith required multiple counts by different observers (Ralston \& Williams 1988, Morales-Nin \& Geffen 2015). However, those repeat counts did not remove unacceptably high error rates (Takács et al. 2016). On the other hand, a single SEM sample, despite being expensive and time consuming, does not require multiple otoliths per age group because it offers precise and accurate micro-increment counts (Takács et al. 2016). SEM examination of otoliths from each suspected age group also offers a means of cross-checking micro-increments across the entire life history of a population.

\subsection{Age groups}

We resolved the problem of icefish aging by counting daily micro-increments in otoliths by LM, checked by SEM and tested for the existence of the smallest micro-increment common for each age group, together with correlating otolith dimensions with age groups. We accurately estimated the ages of fish up to $6+\mathrm{yr}$ old, indicating that their maximum size may be achieved in $4 \mathrm{yr}$ and that individuals rarely survive beyond 6 yr.

We did not observe strong seasonal differences in micro-increments, but slightly lower winter growth rates may be related to low food availability (Traczyk \& Meyer-Rochow 2019). Presumably, slightly higher summer growth rates in larval $P$. georgianus are maintained because the fish migrate to and remain in 
deep cold water below $400 \mathrm{~m}$, where warming does not occur (Whitehouse et al. 2008).

The edges of larval otoliths are more strongly calcified than their centers, with little connecting protein associated with the number of daily micro-increments, which indicates that hatching occurs in winter. This was also confirmed in field observations by North (1990) and suggests subsequent migration to deep cold waters and a larger and stockier body to save energy. On the basis of the observed changes in the growth of the otoliths, we conclude that the earliest mark is identifiable in $1.3 \mathrm{~cm}$ larvae and indicates a June-July hatching period; thus, a $7.4 \mathrm{~cm}$ juvenile fish collected in late January may have been 240$302 \mathrm{~d}$ old. Others estimated that hatching occurred in May-June from April-May spawners (Olsen 1955, Permitin 1973, Chojnacki \& Palczewski 1981). The start and $1 \mathrm{~mm}$ length of an additional primordium as the juveniles migrate to deeper water in January represents a second January of life. Otoliths of $7.4 \mathrm{~cm}$ juveniles (age group 0) caught in January displayed 40-60 relatively wide daily micro-increments indicative of the fast growth they experience when nearshore at depths of 50-70 m (Efremenko 1979, North 1991). Narrower daily micro-increments of older larvae within the second primordium (Fig. 3C) suggest that they had migrated to deeper and colder waters below 250 m (Traczyk \& Meyer-Rochow 2019). A doubling of otolith length up to age group III indicates that the larvae, juveniles and adults exhibit vertical migrations (Mucha 1980, North 1990). Age group III fish (the first to reach sexual maturity and migrate inshore to spawn) also have increased collicula lengths that facilitate balance adjustments when swimming faster horizontally and in waters where currents are stronger and temperatures are higher. Age group IV-VI icefish have markedly larger gonads that change the center of body mass and alter their balance, which is reflected in increased otolith length and circularity. The narrowing micro-increment widths and reduced changes in total length among group IV-VI fish are a consequence of the slower growth rates of aging icefish. Also, the changes in body and otolith mass and shape caused by gonads are greater for females than males in older age groups of $P$. georgianus because eggs are much larger than sperm.

To estimate age structure from lengths of older icefish requires subtracting from them the contribution of age groups appropriate to modes and numbers that shape bimodal frequencies (Magnifico 2007). This is useful to correct fish stock assessments (Sosiński \& Paciorkowski, 1993, Everson et al. 1999) and to pre- vent species from being overexploited. Estimates of age groups based on otolith readings can assign precise ages to individuals, which improves research accuracy and precision and provides an additional means of age estimation (Traczyk \& Meyer-Rochow 2019).

\subsection{Feeding strategy}

There is no agreement upon the causes of daily otolith micro-increments in icefish, but the causes likely include feeding patterns (Gjøsaeter et al. 1984). Adult icefish live in semi-darkness, but daytime variability in activity has been described for $P$. georgianus and other Antarctic fishes, including their larvae (North 1990), and otolith micro-increments are more regular for vertically migrating species such as $P$. georgianus (Pannella 1974). The krill food base of $P$. georgianus generates low-frequency vibrations (50-200 Hz, $50 \mathrm{~N} \mathrm{~m}^{-2}$ ), producing one range of frequencies at one depth range and different ranges at different depths. During the day, krill migrate into the euphotic zone to feed, but at night they migrate to deeper cold water. Channichthyid icefishes like $P$. georgianus have photoreceptors that are adapted to operate in dim light (Miyazaki et al. 2011), but they can locate their migrating food even in total darkness via their otoliths and lateral line system (Montgomery \& Macdonald 1987).

\subsection{Differences between sub-Antarctic and Antarctic zones}

Largely based on the lognormal distribution of the individual variability of otolith mass, we believe that the sub-Antarctic and Antarctic zones are inhabited by a homogeneous population of $P$. georgianus, whose distribution is unimodal rather than bimodal. A unimodal distribution fits our empirical data of all age groups and putative populations.

The distribution of a species in Antarctic waters is strongly connected with the icy environment, fish activity and antifreeze proteins (Bilyk 2011). Fish in different locations and age groups differ from each other because of somatic growth conditions. For example, fish in age groups up to III were numerous in the cold water to the west and south of King George Island, but older mature P. georgianus were more abundant in the warmer waters north-east of the South Orkney islands. A similar distribution pattern applies to $P$. georgianus at South Georgia. 
South Georgia P. georgianus hatch in June, but in the Antarctic zone, hatching occurs 3 mo later, so that their otoliths will be lighter by 3 mo ( 0.0034 g). Because of that delay, $21 \mathrm{~cm} P$. georgianus of age group I from South Georgia have an otolith mass of $0.0171 \mathrm{~g}$, whereas those of the Antarctic zone have otolith masses of $0.0171-0.0034=0.0137 \mathrm{~g}$. Daily increment counts, external otolith morphology and otolith mass are influenced by the environment, as are somatic and reproductive growth (Traczyk \& Meyer-Rochow 2019). Analyzing the width and pattern variability of the otolith micro-increments of $P$. georgianus individuals from sub-Antarctic South Georgia and the Antarctic zone helps us understand why P. georgianus from the Palmer Archipelago, South Orkney and South Georgia islands exhibit subtle differences.

Western P. georgianus from the Palmer Archipelago possess more dorso-ventrally flattened bodies that are better adapted for benthic life, whereas eastern P. georgianus from South Orkney are more laterally compressed and seem more adapted for pelagic life. In cold years, adult $P$. georgianus concentrate on the northeast side of South Georgia, whereas young fish aggregate on the opposite side of the island. Based on body and otolith parameters, specimens from South Georgia show no admixture from other $P$. georgianus populations, even if fish from South Orkney of the cold Antarctic zone, for example, are larger than those from sub-Antarctic South Georgia (Jakubowski 1971, Traczyk et al. 2020).

Assuming a homogeneous population, how can we explain the observed size differences? The smallest immature individuals are present to the west of the Palmer Archipelago, whereas older mature and larger fish abound on the opposite side to the east of South Orkney Island. The habitats differ in temperature, and likely in salinity and food availability. Such environmental differences attract different age groups (including those seeking to avoid predation by larger $P$. georgianus). Different fish populations of different Antarctic islands may differ demographically, but their similar overall growth data suggest homogeneity (Damerau et al. 2014). Homogeneity can in fact be maintained by an occasional inflow of just 5 fish to the population (Papetti et al. 2009). P. georgianus sizes also differ by geographic location because of the seasonal succession indicated by the timing of winter hatching and the migration of age groups (Mucha 1980, Traczyk \& Meyer-Rochow 2019, Traczyk et al. 2020).

Thus, support for the assumption that connections between island populations exist is based on 3 lines of evidence: (1) Larvae, possessing sensory struc- tures enabling them to detect distant environments, can swim with or against ocean currents just like krill can (Witek et al. 1988). (2) Oscillations of the northern and southern ice edges (Murphy et al. 2013), which change current directions and larval nursery zones and krill food sources (Sahrhage 1988), also affect the distribution of icefish larvae (Traczyk et al. 2020). (3) In warm years with a shortage of krill derived from the Antarctic zone, the largest $P$. georgianus adults cross the open sea between South Georgia and Shag Rock (Traczyk et al. 2020), confirming analyses that provided evidence of occasional gene flow over thousands of kilometers (Damerau et al. 2014).

Therefore, icefish gene flow is aided by their habitats, namely the shelves of the islands of the Scotia Sea Arc, which are all connected by underwater mountains. The prevalent West Wind Drift creates a relatively stable biological and oceanographic continuum with regard to water temperature and ice cover and has been affecting the region from the Palmer Archipelago to South Georgia for the last 14 million years (Sahrhage 1988). Our otolith analyses from specimens of different regions of the sub-Antarctic and Antarctic zone further support the assumption of a homogeneous unimodal population of $P$. georgianus in this region of the Southern Ocean.

\section{CONCLUSIONS}

There are 8 advantages of the methods presented in this paper: (1) Acetate replicas of otoliths viewed by LM reveal the regularity of daily micro-increments, and the SEM demonstrates the larval microincrements of the entire otolith nucleus as well as the daily micro-increment variability with age (Fig. 3). Previously, only micro-increments at the outer nucleus had been examined (Radtke \& Hourigan 1990) and had failed to detect the micro-increments of older fish (Chojnacki \& Palczewski 1981, Ralston \& Williams 1988). (2) SEM images and high-resolution LM facilitate visualization and automated daily micro-increment counting in icefish larvae and adults that cannot be accurately or precisely achieved by LM images of poor resolution (Fig. 3) that result in considerable observer subjectivity and uncertainty (Ralston \& Williams 1988). (3) Measuring otolith masses and 2 dimensions of radii offer simple and straightforward age estimates for Pseudochaenichthys georgianus and other species of icefish (Radtke 1990, Traczyk 2015a,b). (4) Taking the changed directionality of otolith radii into account 
facilitates reliably relating otolith growth to different age groups. Previously, examination of only 1 dimension in otolith radii indicated interrupted growth in older icefish and irregular or reduced deposition of daily micro-increments, thereby precluding reliable daily micro-increment counting for older icefish. (5) Linking otolith micro-increments and changes in shape among age groups facilitates accurate and precise recognition of different $P$. georgianus age groups and presumably those of other icefish species. (6) Our results facilitate corrections to historical data obtained by traditional LM methods of age estimation (Kock 1989) and provide life-history insights between species and their environments, including responses to climate changes (Traczyk \& MeyerRochow 2019, Traczyk et al. 2020). (7) Identifying natural icefish age groups facilitates testing whether populations conform to a uni- or multimodal distribution, thereby allowing determination of whether those populations represent distinct evolutionarily significant units. (8) We show that locally rapid growth of otoliths is initiated at additional primordia, not only by the increased width of daily micro-increments, as long as those daily micro-increments are counted along the radius distance.

Acknowledgements. We thank all those concerned with collecting and sharing the icefish material, and all who offered their help and advice, in particular J. Sosiński, E. Stanek, T. Linkowski, R. Radtke, K. H. Kock, A. North, R. Drozdowski and A. Kunicki. We deeply appreciate the Polish Sea Fisheries Institute and London Imperial College for supporting 2 cruises on the RV 'Prof. Siedlecki' and the trawler 'Hill Cove,' and providing laboratory equipment, references, advice and assistance. We thank the ship captains (Janusz Olszowy, Treba Doyle), science officers (Janusz Kalinowski, Józef Sosiński, Stanisław Rakusa-Suszczewski, Inigo Everson, Roman Długosz, Aida Fernandes-Rios), Jan Michalak and the other 48 crewmen involved in sampling under sometimes challenging conditions. We are grateful to the managers of the Electron Microscopy Laboratory, Institute of Experimental Physics at the University of Gdańsk, and the Scanning Electron Microscopy Laboratory at Gdańsk Polytechnic School for equipment and advice. V.B.M.R. thanks the staff of Poland's Antarctic Arctowski Base for their hospitality during a visit in the 2000 Austral summer, and the support of C. Jung via the Basic Science Research Program of the National Research Foundation of Korea (NRF-2018 R1A6A1A03024862) enabling us to complete this study. The order of the authors' names reflects the sequence in which the individuals joined in this project.

\section{LITERATURE CITED}

Agnew DJ, Gutierrez NL, Stern-Pirlot A, Hoggarth DD (2017) The MSC experience: developing an operational certification standard and a market incentive to improve fishery sustainability. J Mar Sci 71:216-225
Bilyk K (2011) The influence of environmental temperature on the thermal tolerance of Antarctic notothenioid fishes. $\mathrm{PhD}$ thesis, University of Illinois, Urbana, IL

*ampana SE, Neilson JD (1985) Microstructure of fish otoliths. Can J Fish Aquat Sci 42:1014-1032

CCAMLR (Convention on The Conservation of Antarctic Marine Living Resources) (2019) CCAMLR Statistical Bulletin, Vol 31. https://www.ccamlr.org/en/document/data/ccamlrstatistical-bulletin-vol-31 (accessed 29 August 2020)

CCAMLR (2020) Scientific observer's manual-finfish fisheries. https://www.ccamlr.org/en/document/science/ scientific-observers-manual-\% E $2 \% 80 \% 93$-finfishfisheries-\%E2\%80\%93-version-2020 (accessed 29 August 2020)

Chojnacki J, Palczewski P (1981) Age and growth of Pseudochaenichthys georgianus Norman 1937 (family Chaenichthyidae) of the South Georgia region. Pol Polar Res 2:145-157

Damerau M, Matschiner M, Salzburger W, Hanel R (2014) Population divergences despite long pelagic larval stages: lessons from crocodile icefishes (Channichthyidae). Mol Ecol 23:284-299

Drozdowski R (1992) Struktura nadsubtelna Zeemanowska linii należących do przejść pomiędzy poziomami konfiguracji 5s2 5p6s i 5p6s 5s25pgs jonu antymonu 121 sb II. $\mathrm{PhD}$ thesis, Gdańsk University (in Polish)

Efremenko VN (1979) Opisane lićinok śesti vidov ryb semejstva Chaenichthyidae iz Morja Scotia. Vopr Ikhtiol 19: 458-469

Efremenko VN (1983) Atlas of fish larvae of the Southern Ocean. Cybium 7:1-74

Everson I (1994) Report of the working group on fish stock assessment. CCAMLR Annex 4:1-17

Everson I, Parkes G, Kock KH, Boyd IL (1999) Variation in standing stock of the mackerel icefish Champsocephalus gunnari at South Georgia. J Appl Ecol 36:591-603

Ferreira T, Rasband W (2011) The imageJ user guide-IJ 1.45. http://imagej.nih.gov/ij/docs/guide (accessed 22 August 2020)

*Florin AB, Hüssy $\mathrm{K}$, Blass $\mathrm{M}$, Oesterwind $\mathrm{D}$ and others (2018) How old are you - evaluation of age reading methods for the invasive round goby (Neogobius melanostomus, Pallas 1814). J Appl Ichthyol 34:653-658

Gabriel B (1982) Biological scanning electron microscopy. Van Nostrand Reinhold Company, New York, NY

* Geffen AJ (1983) The deposition of otolith rings in Atlantic salmon, Salmo salar L., embryos. J Fish Biol 23:467-474

Geissinger HD (1976) Intermicroscopic (LM, SEM, TEM) correlation. In: Hayat MA (ed) Principles and techniques of scanning electron microscopy, Vol 5. Van Nostrand Reinhold, New York, NY, p 94-121

Ghigliotti L, Ferrando S, Carlig E, Di Blasi D and others (2017) Reproductive features of the Antarctic silverfish (Pleuragramma antarctica) from the western Ross Sea. Polar Biol 40:199-211

Gjøsaeter J, Dayaratne P, Bergstad OA, Gjøsaeter H, Sousa MI, Beck IM (1984) Ageing tropical fish by growth rings in the otoliths. FAO Fish Circ 776. FAO, Rome

Glen S (2015) Multimodal distribution definition and examples. https://www.statisticshowto.com/multimodaldistribution/ (accessed 22 August 2020)

Hecht T (1987) A guide to the otoliths of Southern Ocean fishes. S Afr J Antarct Res 17:1-87

Jakubowski M (1971) Whitebloodedness and other unique futures of Antarctic fish. Przegl Zool 15:262-272 
Kellermann KA, Gauldie RW, Ruzicka JJ (2002) Otolith microincrements in the Antarctic fishes Notothenia coriiceps and Pseudochaenichthys georgianus. Polar Biol 25: 799-807

Kock KH (1981) Fischereibiologische Untersuchungen an drei antarktischen Fischarten: Champsocephalus gunnari Lonnberg, 1905, Chaenocephalus aceratus (Lonnberg, 1906) und Pseudochaenichthys georgianus Norman, 1937 (Nototheniidae, Channichthyidae). Mitt Inst Seefisch 32: $1-226$

Kock KH (1989) Results of the CCAMLR Antarctic fish otoliths/scales/bones exchange system. Select Sci Pap VIII/BG/46, SC-CAMLR, p 197-226

Kock KH (2005) Antarctic icefishes (Channichthyidae): a unique family of fishes. Polar Biol 28:862-895

Kock KH, Kellermann A (1991) Reproduction in Antarctic notothenioid fish. Antarct Sci 3:125-150

Kock KH, Jones C, Wilhelms S (2000) Biological characteristics of Antarctic fish stocks in the Southern Scotia Arc region. CCAMLR Sci 7:1-41

Kota M (2016) ImageJ macro language. In: Kota M (ed) Bioimage data analysis. Wiley, Weinheim, p 19-62

La Mesa M (2004) The role of notothenioid fish in the food web of the Ross Sea shelf waters: a review. Polar Biol 27: 321-338

Linkowski TB, Rembiszewski JM (1978) Ichthyological observations off the South Georgia coasts. Pol Arch Hydrobiol 25:697-704

Magnifico G (2007) New insights into fish growth parameters estimation by means of length-based methods. PhD dissertation, University of Rome

* May RM, Beddington JR, Clark CW, Holt SJ, Laws RM (1979) Management of multispecies fisheries. Science 205: 267-277

Meyer-Rochow VB, Cook I, Hendy CH (1992) How to obtain clues from the otoliths of an adult fish about the aquatic environment it has been in as a larva. Comp Biochem Physiol A Physiol 103:333-335

Militelli MI, Macchi GJ, Rodrigues KA (2015) Maturity and fecundity of Champsocephalus gunnari, Chaenocephalus aceratus and Pseudochaenichthys georgianus in South Georgia and Shag Rocks Islands. Polar Sci 9:258-266

Miyazaki T, Iwami T, Meyer-Rochow VB (2011) The position of the retinal area centralis changes with age in Champsocephalus gunnari (Channichthyidae), a predatory fish from coastal Antarctic waters. Polar Biol 34:1117-1123

* Montgomery JC, Macdonald JA (1987) Sensory tuning of lateral line receptors in Antarctic fish to the movements of planktonic prey. Science 235:195-196

Morales-Nin B, Geffen AJ (2015) The use of calcified tissues as tools to support management: the view from the 5 th International Otolith Symposium. ICES J Mar Sci 72: 2073-2078

Mucha M (1980) Characteristics of South Georgia icefish (Pseudochaenichthys georgianus, Norman) from the region of South Georgia Island (Antarctic) in the years 1977-1979. Pol Polar Res 1:163-172

Murphy EJ, Hofmann EE, Watkins JL, Johnston NM and others (2013) Comparison of the structure and function of Southern Ocean regional ecosystems: the Antarctic Peninsula and South Georgia. J Mar Syst 109-110:22-42

North AW (1990) Ecological studies of Antarctic fish with emphasis on early development of inshore stages at South Georgia. PhD dissertation, University of Hull

North AW (1991) Review of the early life history of Antarctic notothenioid fish. In: Di Prisco G, Maresca B, Tota B (eds) Biology of Antarctic fish. Springer-Verlag, Berlin, p 70-86 Olsen BS (1955) A contribution to the systematic and biology of chaenichthyid fishes from South Georgia. Nytt Mag Zool 3:79-93

Pannella G (1974) Otolith growth patterns: an aid in age determination in temperate and tropical fishes. In: Bagenal TB (ed) The ageing of fish. Unwin Brothers Ltd, Surrey, p 27-32

*Papetti C, Susana E, Patarnello T, Zane L (2009) Spatial and temporal boundaries to gene flow between Chaenocephalus aceratus populations at South Orkney and South Shetlands. Mar Ecol Prog Ser 376:269-281

Permitin JE (1973) Plodovitost i biologija rozmnozenija belokrovych (sem. Chaenichthyidae), ugretreskovych (sem. Muraenolepidae) i antarkticeskich ploskonosov (sem. Bathydraconidae) moria Skorza (Antarktika). Vopr Ikhtiol 13:245-258

Peterson CGJ (1981) Eine Methode zur Bestimmung des Alters und des Wuchses der Fische. Mitt Dtsch Seefisch Ver 11:226-236

Radtke RL (1990) Age determination of the Antarctic fishes Champsocephalus gunnari and Notothenia rossii from South Georgia. Polar Biol 10:321-327

Radtke RL, Hourigan TF (1990) Age and growth of the Antarctic fish Nototheniops nudifrons. Fish Bull 88:557-571

Radtke RL, Shafer DJ (1988) Age and growth estimates of the commercially important Antarctic fishes Champsocephalus gunnari and Nothenia rossii from South Georgia. Antarct J US 23:142-143

Ralston S, Williams AH (1988) Numerical integration of daily growth increments: an efficient means of ageing tropical fishes for stock assessment. Fish Bull 87:1-16

* Rosenberg AA, Beddington JR (1987) Harvesting interacting species of different lifespans. Math Med Biol 4:265-278

Sahrhage D (ed) (1988) Antarctic Ocean and resources variability. Springer, Heidelberg

Schwarzhans W, Carnevale G (2017) Otoliths in situ from Sarmatian (Middle Miocene) fishes of the Paratethys: a first attempt to fill the gap between the otolith and skeletal records of teleost fishes. Swiss J Palaeontol 136:1-6

Salim AS, Thekra LI (2009) Solving linear programming problems by using Excel's solver. Tikrit J Pure Sci 14:87-98

* Sidell BD, O'Brien KM (2006) When bad things happen to good fish: the loss of hemoglobin and myoglobin expression in Antarctic icefishes. J Exp Biol 209:1791-1802

* Ślósarczyk W (1983) Preliminary estimation of abundance of juvenile Nototheniidae and Channichthyidae within krill swarms East of South Georgia. Acta Ichthyol Piscat 13: 3-11

Sosiński J, Paciorkowski A (1993) State of mackerel icefish (Champsocephalus gunnari Lonnberg, 1905) stock from South Georgia area based on Polish biological investigations in 1975-1992. Pol Polar Res 14:407-431

Sosinski J, Szlakowski J (1992) Biological characteristics and biomass estimates of the fish stocks on the South Georgia shelf in the 1986/87-1988/89 seasons. Acta Ichthyol Piscat 22:77-105

Statgraphics (1991) Statgraphics version 5. Reference Manual. STSC Inc, Rockville, MD

Takács P, Vitál Z, Ferincz Á, Staszny Á (2016) Repeatability, reproducibility, separative power and subjectivity of different fish morphometric analysis methods. PLOS ONE 11:e0157890 
Traczyk RJ (2015a) Age, growth and distribution of the Antarctic fish Pseudochaenichthys georgianus based on otolith morphometry. J Environ Sci Eng B 4:53-102

Traczyk RJ (2015b) Age, growth and distribution of the Antarctic fish Chaenocephalus aceratus based on otoliths. J Environ Sci Eng A 4:401-419

Traczyk RJ, Meyer-Rochow VB (2019) Age structure and biomass of the icefish Pseudochaenichthys georgianus Norman (Channichthyidae) between 1978 and 2009: a possible link to climate change. Ocean Polar Res 41: 233-250

Traczyk RJ, Meyer-Rochow VB, Hughes RM (2020) Icefish adaptations to climate change on the South Georgia Island shelf (Sub-Antarctic). Ocean Sci J 55:303-319

Vanella FA, Calvo J, Morriconi E, Aureliano D (2005) Somatic energy content and histological analysis of the gonads in Antarctic fish from the Scotia Arc. Sci Mar 69: 305-316

Whitehouse MJ, Meredith MP, Rothery P, Atkinson A, Ward P, Korb RE (2008) Rapid warming of the ocean around South Georgia, Southern Ocean, during the 20th century: forcing, characteristics and implications for lower trophic levels. Deep-Sea Res I 55:1218-1228

Witek Z, Kalinowski J, Grelowski A (1988) Formation of Antarctic krill concentrations in relation to hydrodynamic processes and social behaviour. In: Sahrhage D (ed) Antarctic Ocean and resources variability. Springer, Heidelberg, p 237-244

Żabrowski M (2000) The osteology and ossification variability of the skull of Antarctic white-blooded fish Chaenodraco wilsoni Regan, 1914 (Channichthyidae, Notothenioidei). Acta Ichthyol Piscat 30:111-126

\section{Appendix}

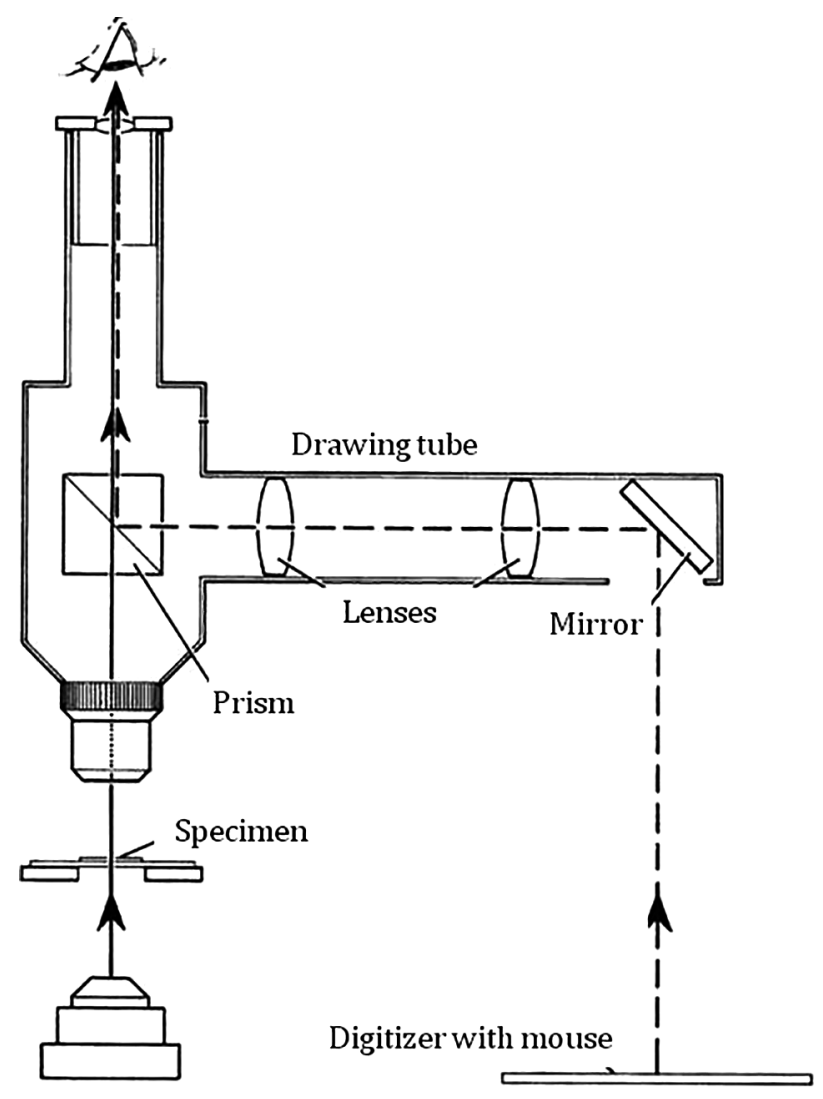

Fig. A1. Microdigitizer used for counting micro-increments and drawing otolith shapes via a light microscope

Editorial responsibility: Helmut Segner, Bern, Switzerland
Submitted: April 23, 2020; Accepted: September 7, 2020

Proofs received from author(s): December 13, 2020 